\title{
Pengaruh Arus dan Tegangan Pengelasan SMAW Baja Karbon Rendah Grade A dan Baja Karbon Rendah Grade B terhadap Sifat Mekanik
}

\author{
(Effect of Current and Voltage Low Carbon Steel Welding SMAW Grade A and Grade B Low \\ Carbon Steel on Mechanical Properties) \\ Muizzaddin Waaddulloh, Sulardjaka, Gunawan $\mathrm{DH}^{\star}$ \\ Program Studi Magister Teknik Mesin, Fakultas Teknik, Universitas Diponegoro \\ JI. Prof. Sudharto, SH. Tembalang, Semarang, Jawa Tengah, Indonesia \\ *e-mail: muizzabdullah589@gmail.com
}

\begin{abstract}
Abstrak
Penelitian ini bertujuan meneliti pengaruh arus dan tegangan terhadap kekuatan tarik, kekuatan impak, kekerasan dan struktur mikro pada hasil pengelasan baja A242 dan baja A588. Pengelasan SMAW menggunakan elektrode E7016 DC+ polaritas terbalik dan elektrode AWS A5.1 tipe RD 260 diameter $3.2 \mathrm{~mm}$ dengan variasi arus pengelasan: $60 \mathrm{~A}, 120 \mathrm{~A}$, dan $180 \mathrm{~A}$, serta variasi tegangan pengelasan: 20,30 dan 40 dengan kecepatan 50 [mm/min]. Jenis kampuh sambungan yang digunakan yaitu single "V" Groove sudut $60^{\circ}$. Pengujian tarik dilakukan berdasarkan standar ASTM E 8M-04, standar pengujian impak berdasarkan ASTM E23, standar pengujian struktur mikro berdasarkan ASTM E407, dan untuk standar pengujian kekerasan mikro vikers berdasarkan ASTM E92. Setelah melakukan pengujian dan pembahasan diketahui bahwa menggunakan variabel arus dan tegangan yang besar sangat memengaruhi dari hasil nilai kekuatan Tarik dan pengujian impak. Hal tersebut disebabkan oleh faktor adanya perbedaan dalam metode pengelasan dan panas yang diterima (heat input), sehingga memiliki struktur mikro yang berbeda pula. Hasil pengujian struktur mikro juga menghasilkan struktur ferit, pearlit dan juga memperlebar butiran las pada daerah weld metal.
\end{abstract}

Kata kunci: kekuatan impak; kekuatan tarik; struktur mikro; kekerasan mikro vikers

\begin{abstract}
This study aims to examine the effect of current and stress on tensile strength, hardness, and microstructure on the welding results of A242 steel and A588 steel. SMAW welding uses E7016 DC electrodes + reverse polarity and AWS A5.1 type RD 260 electrodes $3.2 \mathrm{~mm}$ diameter with welding current variations: $60 \mathrm{~A}, 120 \mathrm{~A}$, and $180 \mathrm{~A}$, and welding voltage variations: 20.30 and 40 with a speed of 50 [mm / minute ] type of seam used is a single " $V$ " angle of 60․ Tests are carried out based on ASTM E 8M-04 standard, standard testing based on ASTM E23, microstructure standard testing based on ASTM E407, and for testing micro vikers hardness standards based on ASTM E92. After testing and discussing it, it is known that using large current and voltage variables greatly affects the results of the strength value, impact testing. This is due to several factors, such as differences in the welding method and heat input, so that they have different microstructures. The microstructure test results also show that it produces a ferrite, pearlite structure and also widens the weld grain in the weld metal area.
\end{abstract}

Keywords: : impact strength; tensile strength; micro structure; micro hardness of vikers

\section{Pendahuluan}

Pengelasan adalah proses penyambungan logam atau non logam yang dilakukan dengan memanaskan material yang disambung hingga temperatur las [1]. Pengelasan merupakan metode penyambungan yang banyak dipakai karena ekonomis, ringan dan cepat. Proses pengelasan busur logam SMAW digunakan dalam kegiatan manufaktur, terutama dalam kapal untuk bagian sekat. 
Perbedaan baja A242 dan A588 selain dari bahan komposisi material juga terletak pada penempatannya pada kontruksi kapal. Baja A242 terletak pada lambung kapal sedangkan baja A588 terletak pada fondasi mesin kapal pengelasan tersebut menggunakan pengelasan busur logam SMAW penyetelan kuat arus dan tegangan pengelasan. Hal ini sangat mempengaruhi hasil las. Bila kuat arus dan tegangan yang digunakan terlalu rendah, maka menyebabkan sulitnya penyalaan busur las listrik. Hal tersebut juga menyebabkan busur las listrik menjadi tidak stabil.

Arus dan tegangan pengelasan juga berpengaruh pada nilai kekerasan dan struktur mikro dari spesimen uji. Kecepatan las yang tinggi dapat menyebabkan kurangnya penetrasi. Jarak gap juga bisa memengaruhi kekuatan sambungan, dan mengakibatkan masukan panas yang diterima per satuan panjang menjadi lebih kecil. Hal ini dapat berdampak pada pendinginan yang cepat, sehingga dapat memperkeras daerah yang panas. Penelitian ini bertujuan meneliti pengaruh arus dan tegangan terhadap kekuatan tarik, kekuatan impak, kekerasan dan struktur mikro pada hasil pengelasan baja A242 dan baja A588 dengan harapan penggunaan baja karbon rendah menjadi lebih luas dengan pertimbangan harga yang masih relatif murah dibandingkan dengan jenis baja karbon lain.

\section{Metode}

Tahapan penelitian yang dilakukan adalah: persiapan bahan baku, pemotongan sampel, pengelasan, pengujian tarik, kekerasan mikro dan pengujian struktur mikro.
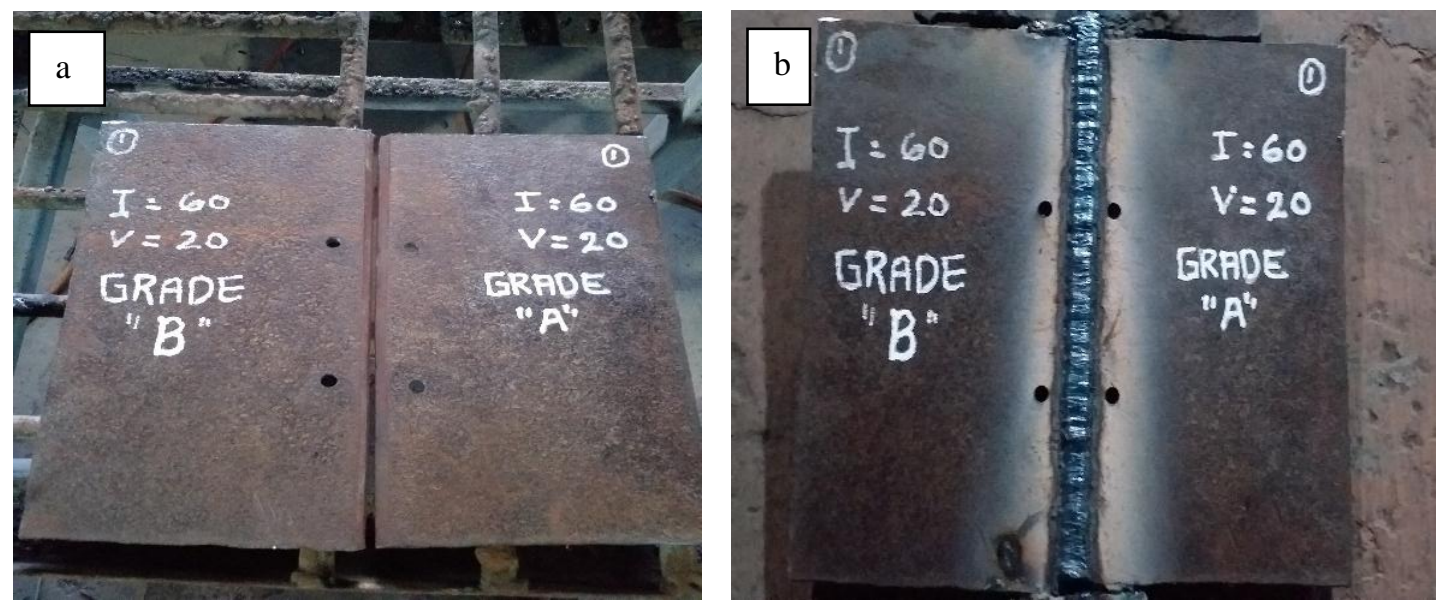

Gambar 2.1 Produk (baja jenis A242 dan A 588) (a) dan Sampel pengelasan (b)

Material yang digunakan untuk penelitian ini adalah baja jenis A242 dan A588. Baja A242 merupakan baja untuk kontruksi kapal pada bagian lambung, sementara baja A588 digunakan untuk kontruksi fondasi mesin [5]. Baja A242 mengandung unsur: C 0,1586\%; Cu 0,086\%; Fe 98,7251\%; Mn 0,7255\%; P 0,0130\%; dan Si 0,2969\%, sedangkan baja A588 mengandung unsur: C 0,1371\%; Cu 0,098\%; Fe 98,8671\%; Mn 0,6791\%; 0,0169\%; dan Si $0,225 \%$ nilai karbon ekuvalen (CE) baja tersebut dapat dihitung dengan rumus sebagai berikut:

$$
\mathrm{CE} / \%=\mathrm{C}+\mathrm{Mn} / 6+((\mathrm{Cr}+\mathrm{Mo}+\mathrm{V}) / 5)+((\mathrm{Ni}+\mathrm{Cu}) / 15)
$$

Proses pengelasan dilakukan dengan jenis sambungan (but joint) dengan jarak gap 2 $\mathrm{mm}$. Pengelasan SMAW dilakukan dengan menggunakan elektrode E7016 dengan diameter $2,4 \mathrm{~mm}$. Pengelasan dilakukan dengan variasi arus: $60 \mathrm{~A}, 120 \mathrm{~A}, 180 \mathrm{~A}$ variasi tegangan: $20 \mathrm{~V}$, $30 \mathrm{~V}, 40 \mathrm{~V}$ dengan kecepatan $50[\mathrm{~mm} / \mathrm{min}]$. 
Penggunaan standar pengujian tarik berdasarkan ASTM E 8M-04, standar pengujian impak berdasarkan ASTM E23, standar pengujian struktur mikro berdasarkan ASTM E407, dan untuk standar pengujian kekerasan mikro vikers berdasarkan ASTM E92. Pada pengujian struktur mikro, terdapat beberapa tahapan yang harus dilalui, seperti: mounting, grindhing, poleshing, dan etching seperti yang di tujukan pada Gambar 2.2

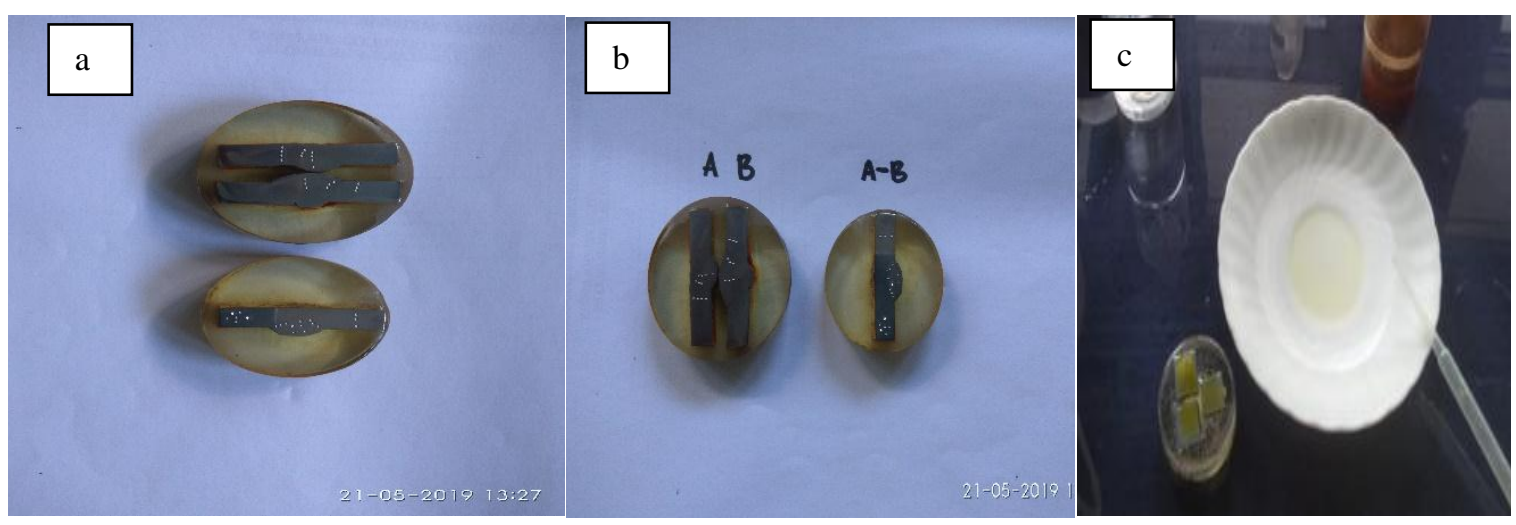

Gambar 2.2 Proses preparasi spesimen: a) proses mounting; b) pemolesan; dan c) proses etching

Gambar 2.2a menunjukkan bahwa proses mounting material dilakukan agar lebih mudah untuk melakukan proses pemolesan. Gambar 2.2b menunjukkan hasil setelah dilakukan grinding, yang kemudian dapat dilanjutkan dengan pemolesan. Hasil tersebut harus benar-benar halus. Selain itu, Gambar 2.2c memperlihatkan proses etching dengan menggunakan $\mathrm{HNO}_{3}, \mathrm{HCl}$, dan alkohol.
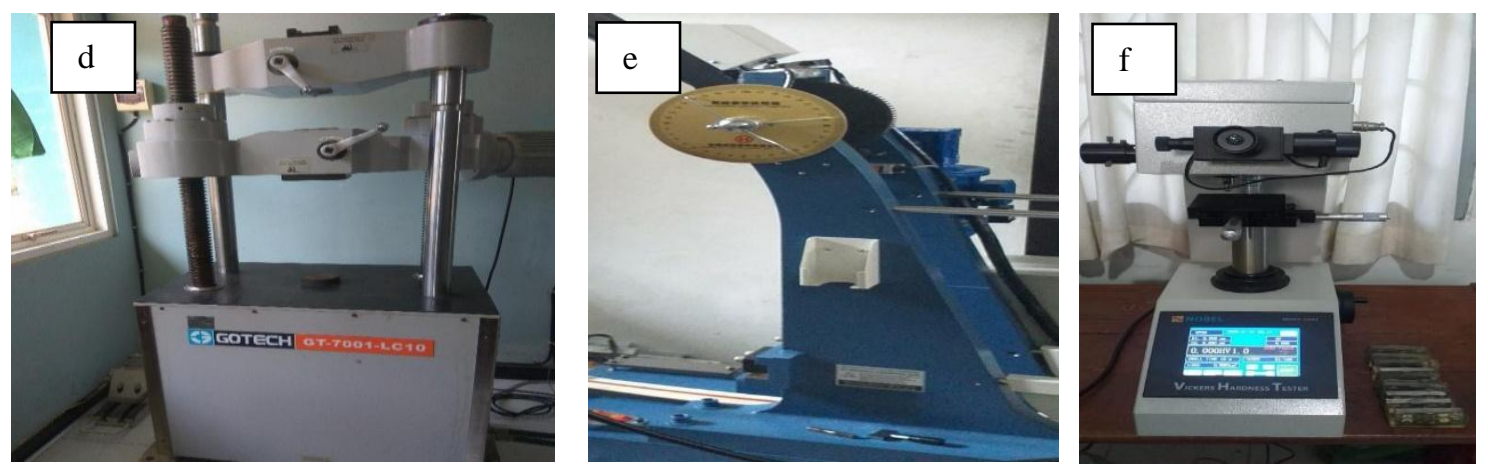

Gambar 2.3 Proses preparasi spesimen: a) proses mounting; b) pemolesan; dan c) proses etching

Gambar 2.3a menunjukkan alat uji tarik dilakukan untuk mengetahui kekuatan tarik. Gambar 2.3b menunjukkan alat pengujian impak. Selain itu, Gambar 2.3c menunjukkan alat pengujian mikro vikers.

\subsection{Proses pengelasan}

Langkah-langkah pengelasan sambungan las $3 G$ ditunjukkan pada Gambar 3.1, sebagai berikut:

1) Membuat sambungan groving $\vee 60^{\circ}$ (Gambar 3.1a) dengan menggunakan mesin bubut;

2) Dilakukan pengelasan layer pertama, kedua dan ketiga untuk menghasilkan WM dan HAZ (Gambar 3.1b);

3) Daerah WM (weld metal) dan HAZ dan Base Metal (Gambar 3.1c). 

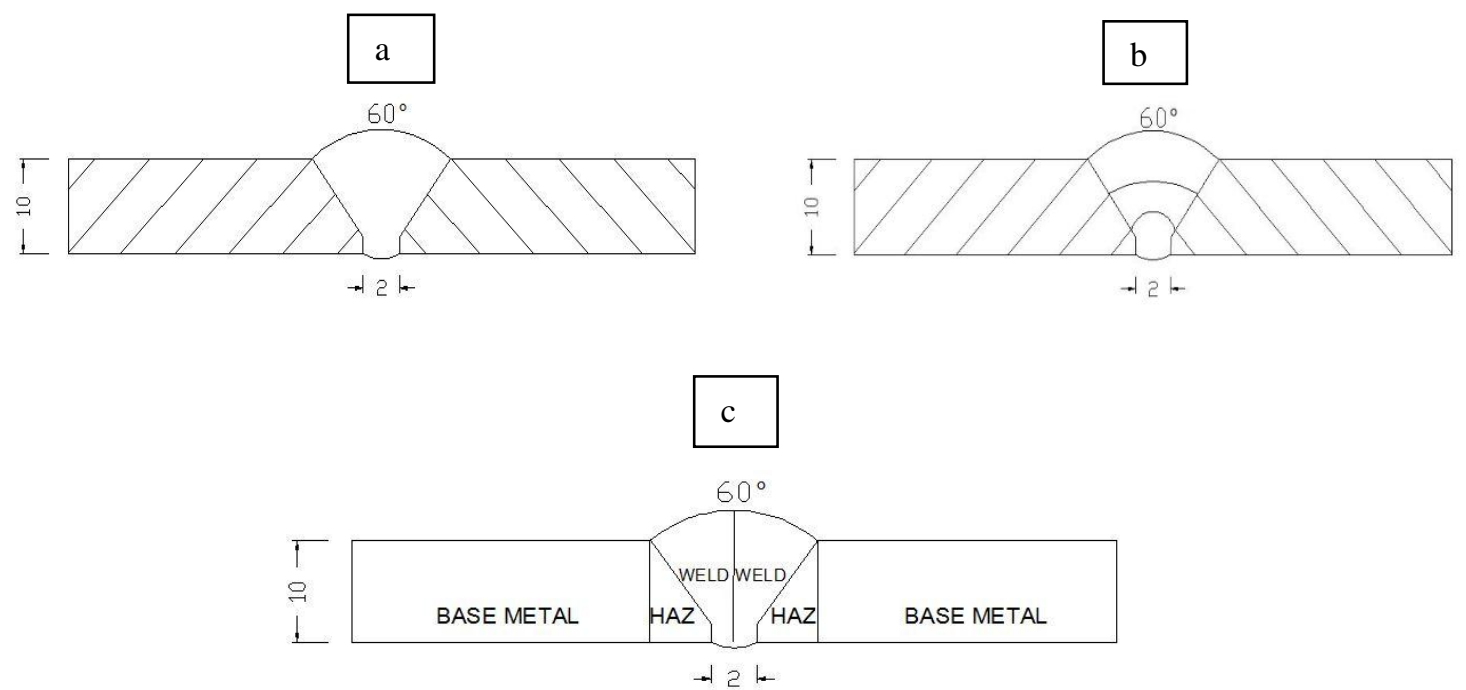

Gambar 3.1 Langkah Pengelasan: a) Pengelasan 3 layer butt join; b)Tembusan Pengelasan 3G; c)Daerah Pengelasan $3 G$

\section{Hasil dan Pembahasan}

3.1 Komposisi kimia base metal

Pada penelitian ini dilakukan perhitungan carbon ekuivalen untuk mengetahui karbon baja A244 dan A588 (Tabel 3.1 dan Tabel 3.2).

Tabel 3.1 Hasil komposisi kimia baja $A 588$

\begin{tabular}{ll}
\hline Element & Content \\
\hline Karbon, C & $0,1586 \%$ \\
Tembaga, Cu & $0,086 \%$ \\
Besi, $F e$ & $98,7251 \%$ \\
Mangan, $M n$ & $0,7255 \%$ \\
Fosfor, & $0,0130 \%$ \\
Silikon, Si & $0,2969 \%$ \\
\hline
\end{tabular}

Tabel 3.1 dan Tabel 3.2 menunjukkan komposisi material yang diuji oleh perusahaan PT. Krakatau Steel dan PT.Gunung Raja Paksi, sebagai fondasi mesin kapal [9].

Tabel 3.2 Komposisi kimia baja $A 242$

\begin{tabular}{ll}
\hline Element & Content \\
\hline Karbon, $C$ & $0,1586 \%$ \\
Tembaga, $\mathrm{Cu}$ & $0,086 \%$ \\
Besi, Fe & $98,7251 \%$ \\
Mangan, $\mathrm{Mn}$ & $0,7255 \%$ \\
fosfor, $P$ & $0,0130 \%$ \\
Silikon, $\mathrm{Si}$ & $0,2969 \%$ \\
\hline
\end{tabular}




\subsection{Hasil Perhitungan Masukan Panas (Heat Input)}

Besarnya masukan panas yang terjadi selama proses pengelasan berlangsung dapat dilihat pada Tabel 3.2. Didefinisikan oleh arus, tegangan dan pengelasan kecepatan untuk rentang pengelasan busur logam terlindung dan dirumuskan sebagai berikut [6]:

$$
\begin{aligned}
& H_{\text {net }}=(60+\mathrm{E}+\mathrm{I}) / 1000 \times \mathrm{S} \\
& \mathrm{E} \quad=\text { Tegangan melintasi busur } / \text { Volts } . \\
& \mathrm{I} \quad=\text { Arus } / \text { Ampere } \\
& H_{\text {net }}=\text { Panas Masuk } / \mathrm{Kj} / \mathrm{mm} . \\
& \mathrm{S} \quad=\text { Kecepatan Pengelasan } / \mathrm{m} / \text { detik } \\
& \text { Perhitungan panas masuk: } \\
& H_{\text {net }}=(60+\mathrm{E}+\mathrm{I}) / 1000 \times \mathrm{S}
\end{aligned}
$$

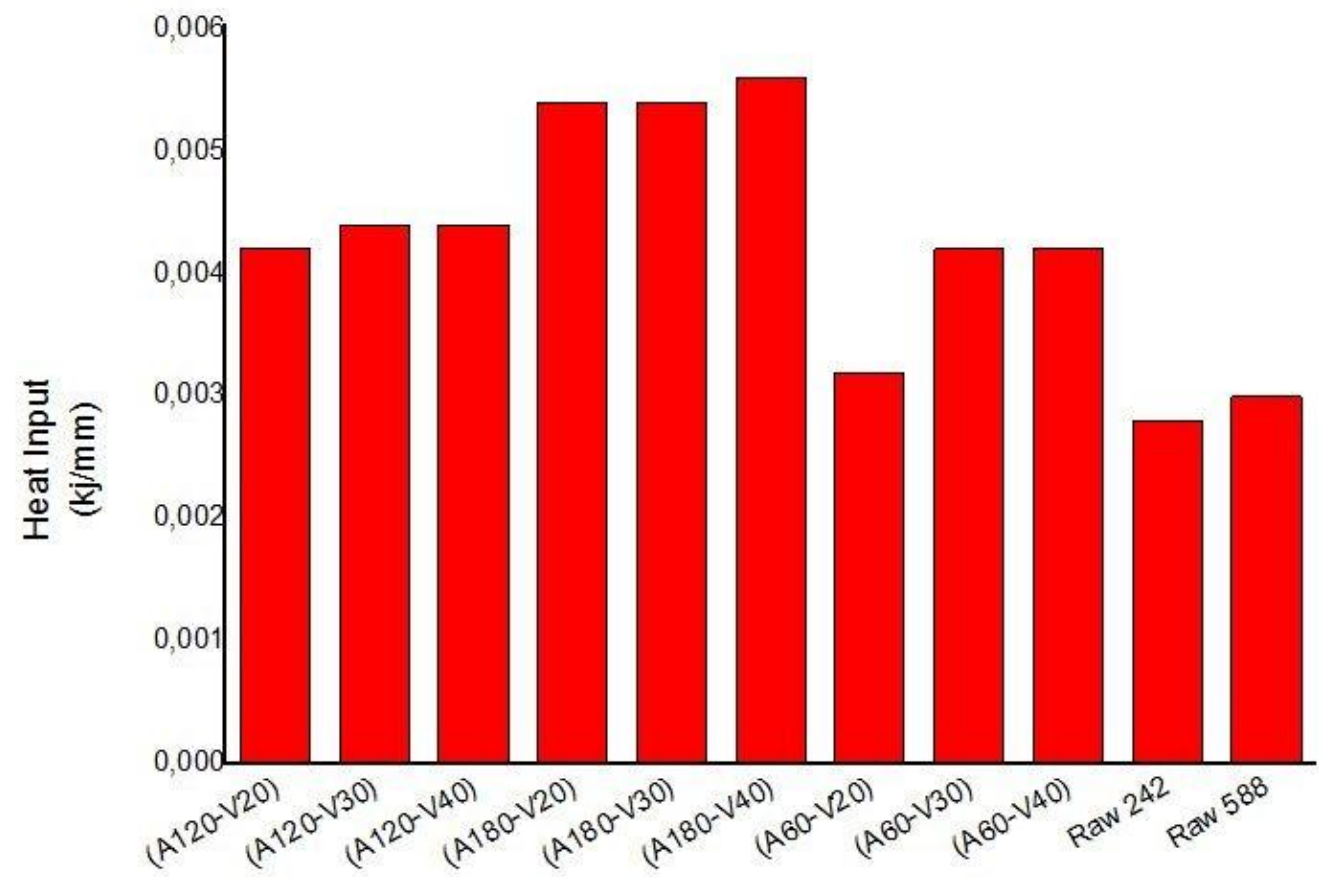

Dari Gambar 3.3 diketahui bahwa terjadi peningkatan total heat input yang dipengaruhi oleh arus pengelasan dan tegangan.

\subsection{Hasil uji tarik}

Pengujian tarik dilakukan dengan menggunakan mesin uji tarik pembuatan spesimen dan prosedur pengujian sesuai standar ASTM E 8M-01. Pada Gambar 3.3 dan Tabel 3.4 dapat dilihat grafik nilai pengujian tarik pada pengelasan SMAW dengan variasi (1) Raw 242 (2) Raw 588 (3) (A60-V20) (4) (A60-V30) (5) (A60-V40) (6) (A120-V20) (7) (A120-V30) (8) (A120-V40) (9) (A180-V20) (10) (A180-V30) (11) (A180-V40). Gambar 3.3 menunjukkan nilai rata -rata tegangan tarik raw material atau tanpa pengelasan (TL), yang lebih kecil dibandingkan dengan nilai rata-rata tegangan tarik metode pengelasan SMAW. Nilai ratarata untuk tegangan tarik raw material yaitu sebesar $449 \mathrm{MPa}$, dengan tegangan tarik ratarata untuk metode pengelasan SMAW sebesar 352 Mpa [13]. 


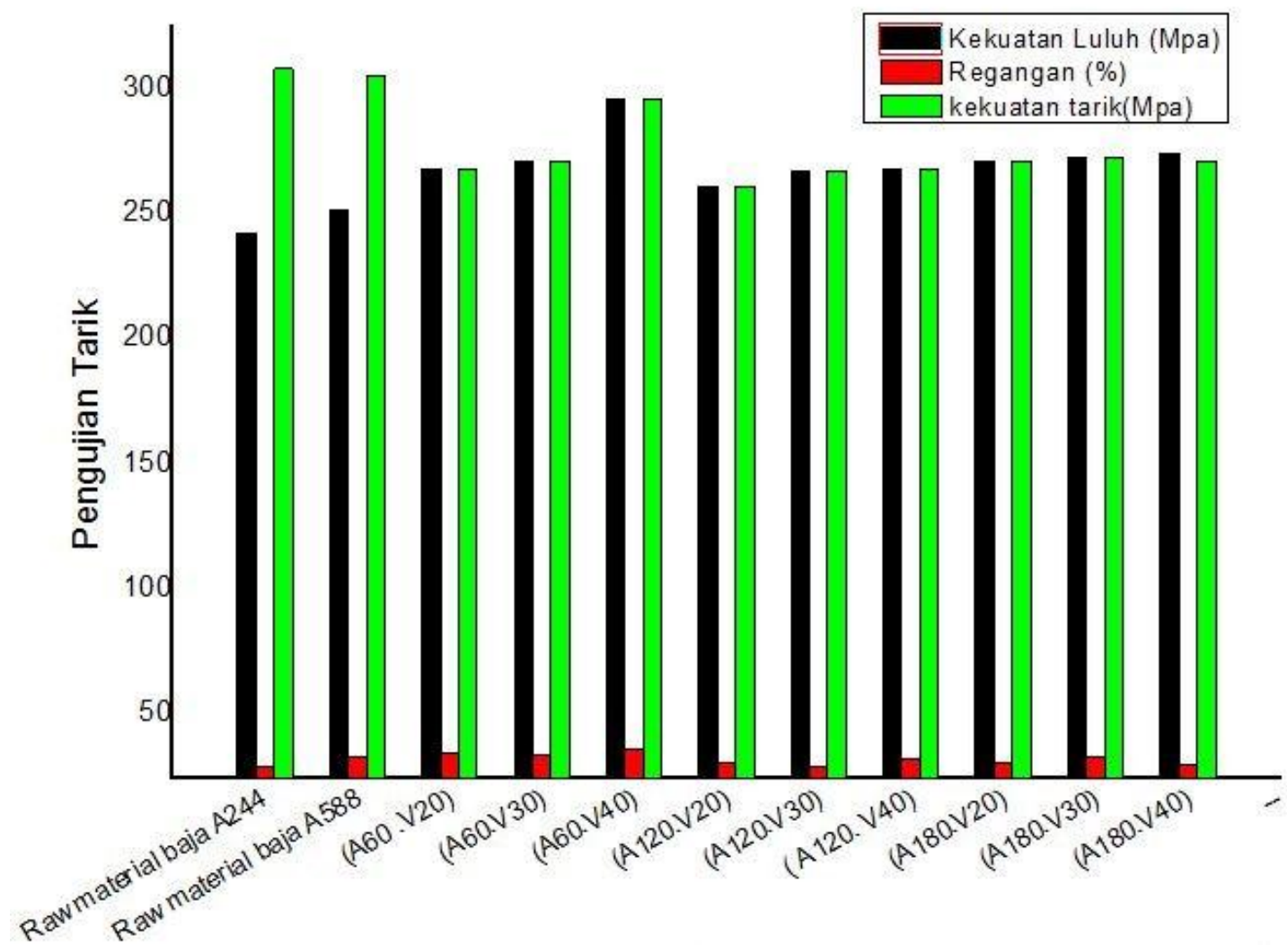

\section{Gambar 3.3. Grafik nilai Kekuatan Tarik dan Kekuatan Luluh MPa}

Dari Gambar 3.3 menunjukkan bahwa nilai kekuatan tarik spesimen (1) Raw 242 (2) Raw 588 (3) (A60-V20) (4) (A60-V30) (5) (A60-V40) (6) (A120-V20) (7) (A120-V30) (8) (A120-V40) (9) (A180-V20) (10) (A180-V30) (11) (A180-V40) mempunyai nilai yang paling kecil di antara raw material. Hasil pengujian tarik terlihat bahwa kekuatan luluh mempunyai nilai rendah dibandingkan dengan nilai kekuatan tarik dengan nilai dari raw material A 242 yaitu $447 \mathrm{MPa}$, diikuti oleh arus $180 \mathrm{~A}$ dengan tegangan $40 \mathrm{~V}$ dengan nilai $382 \mathrm{MPa}$ dan nilai terendah terdapat pada arus $60 \mathrm{~A}$ dengan tegangan $30 \mathrm{~V}$ yaitu $339 \mathrm{Mpa}$. Hal ini menunjukkan bahwa proses pengelasan dengan arus terlalu tinggi maka elektrode akan mencair terlalu cepat dan akan menghasilkan permukaan las yang lebih lebar serta penembusan yang dalam sehingga menghasilkan kekuatan tarik yang rendah dan menambah kerapuhan dari hasil pengelasan[13]._Nilai regangan yang dihasilkan pada tiap spesimen mengalami penurunan pada kenaikan arus dan tegangan. Nilai regangan tertinggi yaitu spesimen A60-V20 dengan rata rata $36 \%$. Pada raw material A 242 nilainya $28 \%$ dan raw material A 588 dengan nilainya $30 \%$. Perbedaan regangan dari setiap spesimen diakibatkan oleh perambatan heat input ke segala arah yang dapat menyebabkan pertumbuhan struktur kristal di daerah yang terpengaruh panas [13]. 
3.5 Pengujian Impak

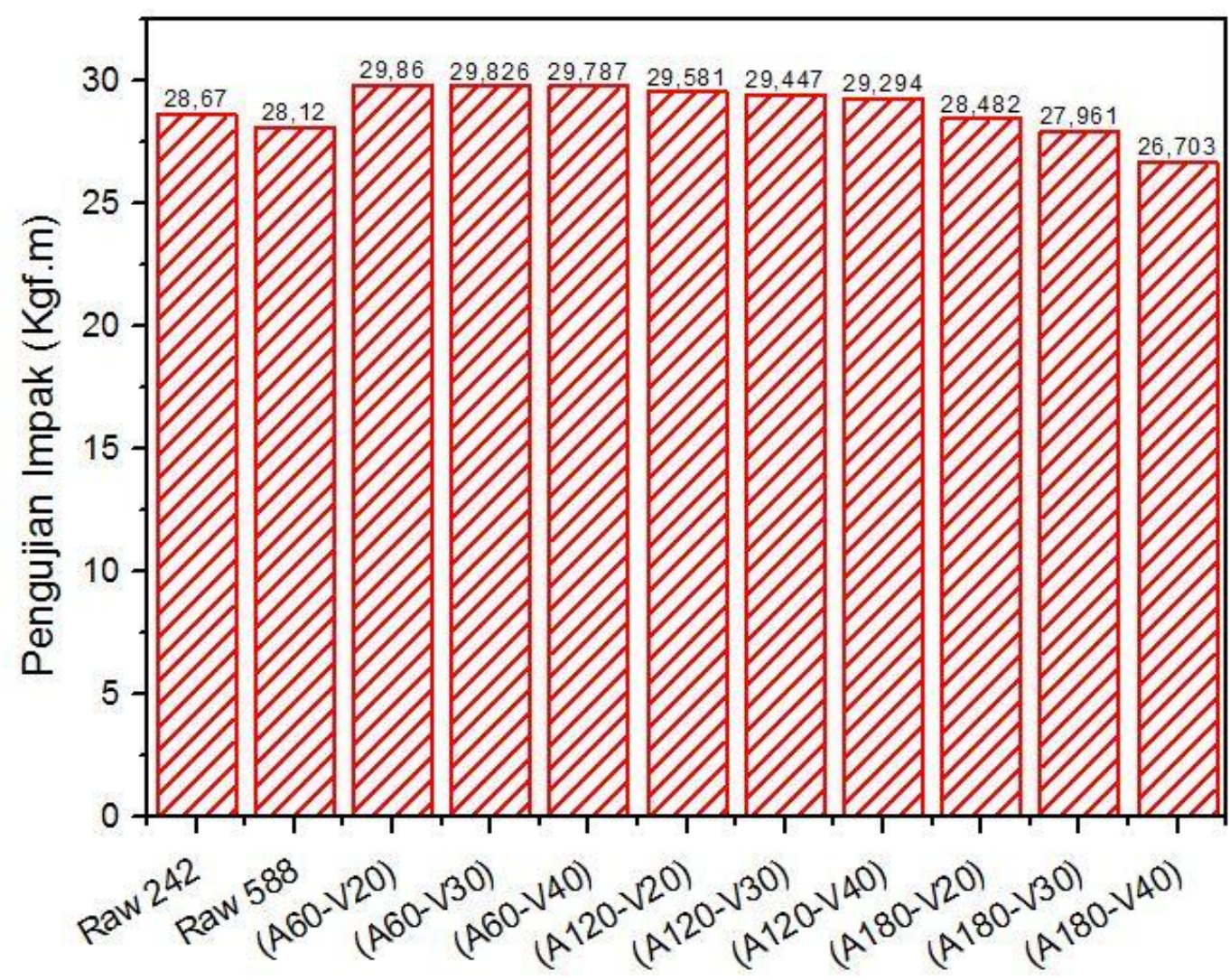

Gambar 3.7. Grafik nilai pengujian impak

Data tabel 3.7 didapatkan bahwa pelat baja karbon grade A dan grade B hasil pengujian impak dan A588 dengan nilai $28,12 \mathrm{Kgf.m}$, nilai tertinggi dari material dengan arus $60 \mathrm{~A}$ dengan tegangan $20 \mathrm{~V}$ dengan nilai sebesar 29,86 Kgf.m.

\subsection{Strulktur mikro}
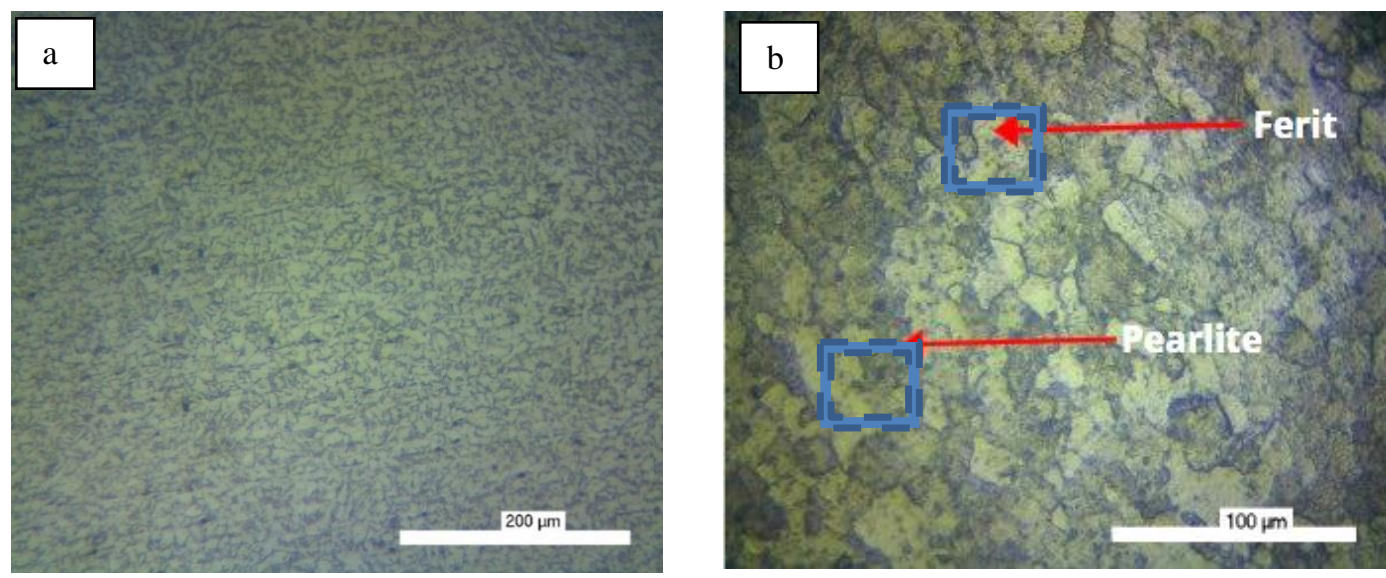

Gambar 3.8. Struktur mikro raw material baja A244 a) hasil $200 x$ perbesaran; b) hasil $400 x$ perbesaran 
Pada hasil pengujian struktur mikro untuk raw material, struktur yang dihasilkan adalah struktur ferit dan struktur pearlit. Struktur ferit memiliki warna putih. Sementara itu, struktur pearlit berwarna abu-abu dan dengan bentuk yang besar (coarse pearlite). Struktur pearlit ini terbentuk dari gabungan 2 fasa, yaitu fasa ferit dan fasa sementit. Pengamatan struktur mikro dilakukan memakai alat optical microscopy dengan perbesaran 200 kali dan 400 kali. Hasil pengujian pengamatan struktur mikro pada raw material baja A242 dan baja A588 disajikan pada Gambar 3.8
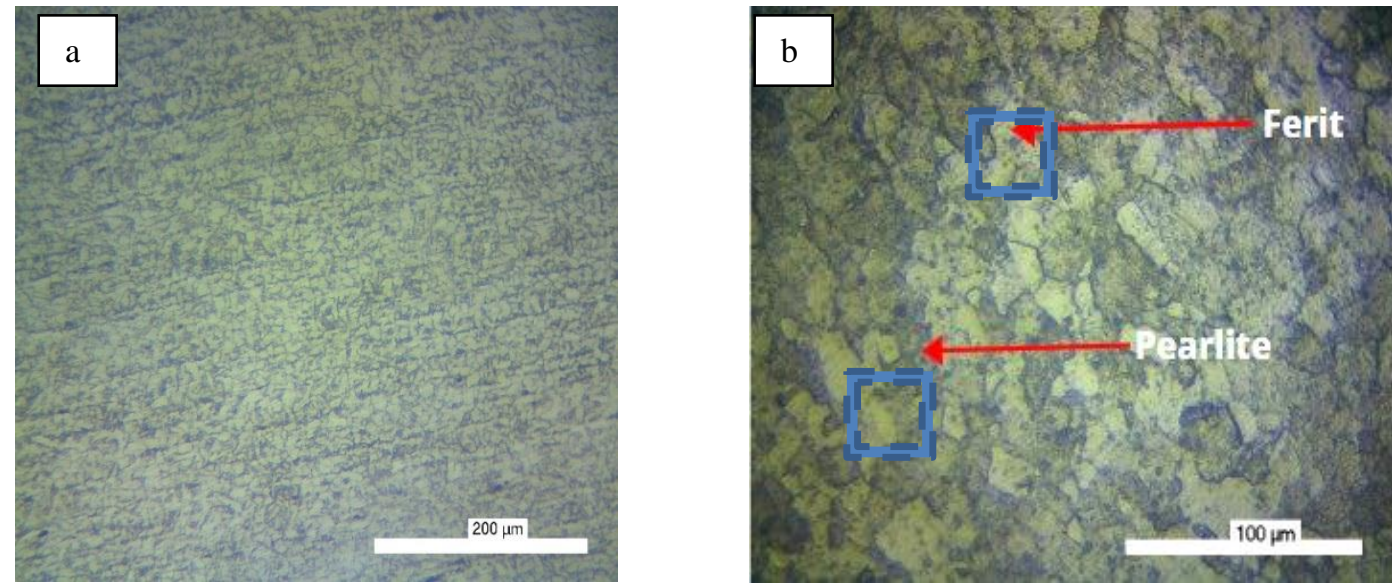

Gambar 3.9. Struktur mikro Raw material baja A588, a. hasil $200 x$ perbesaran, b. hasil $400 x$ perbesaran

Gambar 3.9 menunjukkan struktur mikro daerah base metal pada hasil pengelasan SMAW dengan Daerah HAZ: (a) A60 V20 200 x perbesaran; (b) A60 V30 200 x perbesaran; (c) A60 V40; (d) A120 V20 200 x perbesaran; (e) A120 V30 200 x perbesaran; (f) A120 V40 $200 \times$ perbesaran; (g) A180 V20 $200 \times$ perbesaran; (h) A180 V30 $200 \times$ perbesaran; (i) A180 V40 $200 \times$ perbesaran. Butir-butir ferrite yang berwarna putih (terang) mendominasi, sedangkan fasa pearlite lebih sedikit (berwarna gelap). Butir ferrite cenderung lebih halus dan lunak sedangkan butir pearlite lebih kasar dan keras karena mengandung karbon. Adanya fasa ferrite dan pearlite pada base metal ini menandakan bahwa baja bersifat tidak keras namun ulet [14].
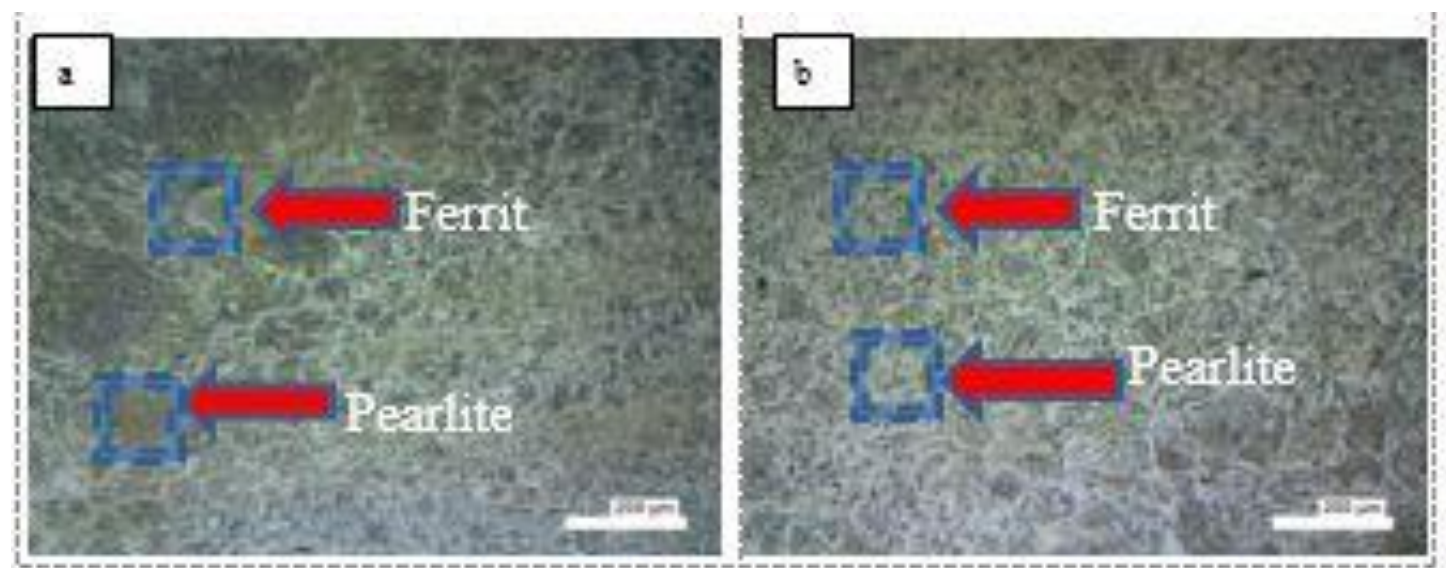


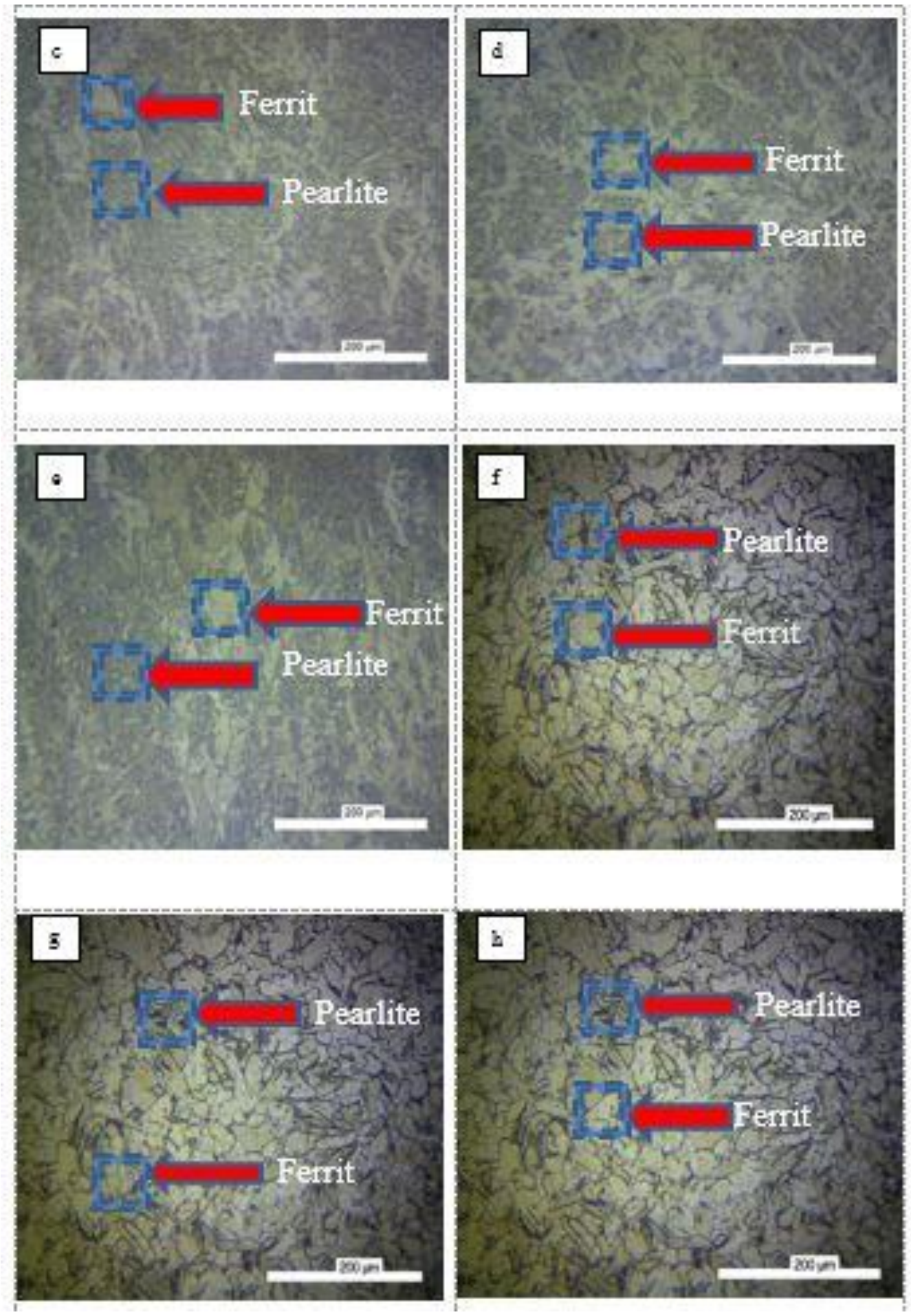




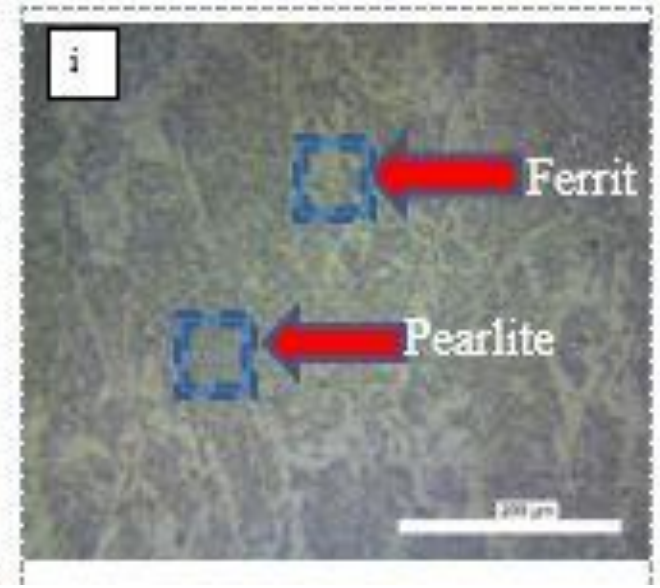

Gambar 3.10 menunjukkan struktur mikro daerah HAZ pada hasil pengelasan SMAW dengan daerah; (a) HAZ (A60-V20 200) x perbesaran; (b) HAZ (A60-V30) $200 \times$ perbesaran; (c) HAZ (A60-V40) 200 x perbesaran; (d) (A120-V20) 200 x perbesaran; (e) (A120-V30) 200 x perbesaran;(f) (A120-V40) 200 x perbesaran; (g) (A180-V20) $200 x$

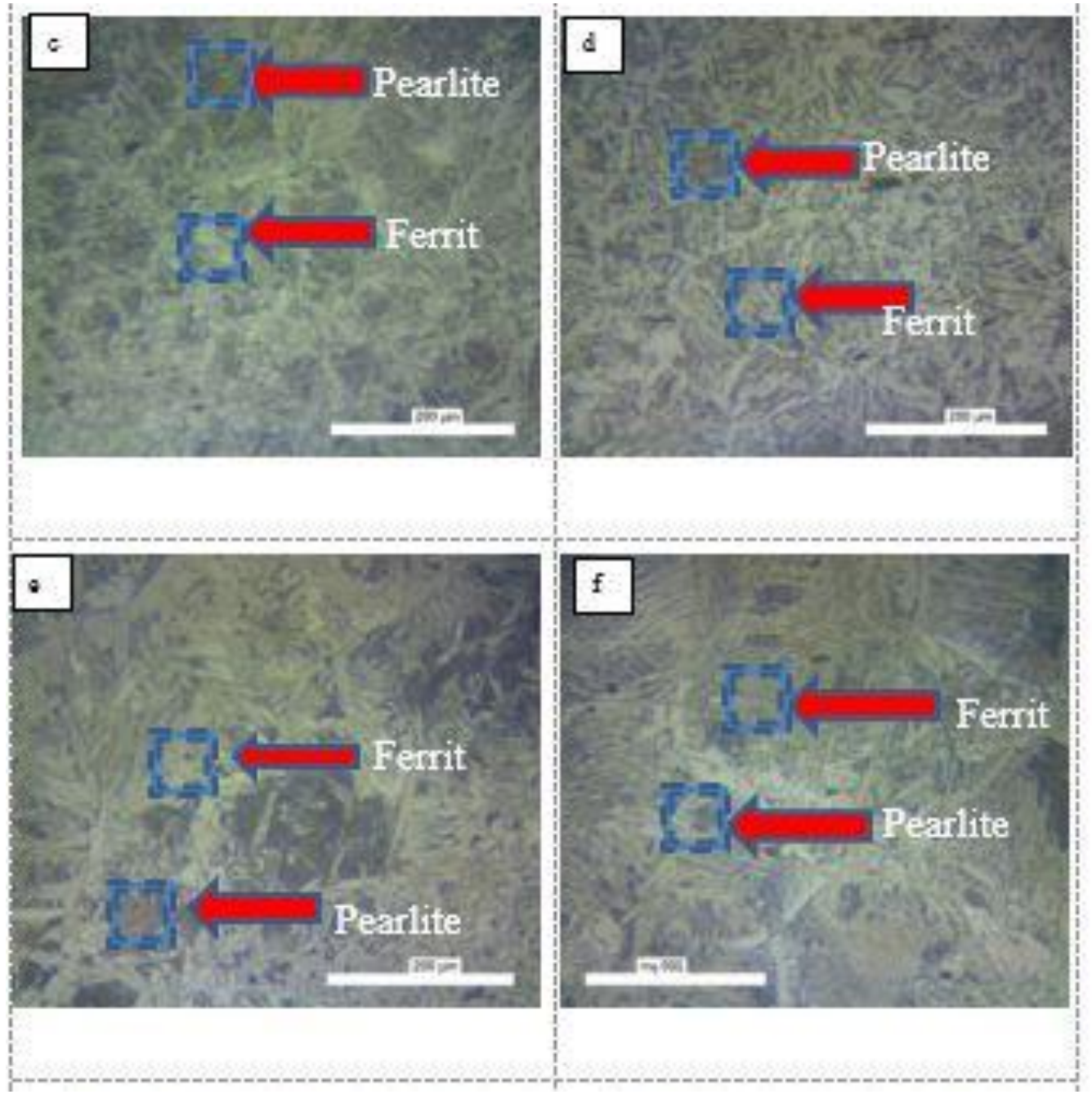


perbesaran; (h) (A180-V30) $200 \times$ perbesaran; (i) (A180-V40) $200 \times$ perbesaran. Struktur mikro yang terbentuk pada daerah HAZ yaitu pearlite dan ferit. Proses pengelasan yang dilakukan menyebabkan rata-rata fasa pearlite di daerah HAZ mengalami penurunan dibandingkan dengan daerah base metal. Ukuran butir fasa pearlite berubah menjadi lebih halus dibandingkan dengan daerah base metal.

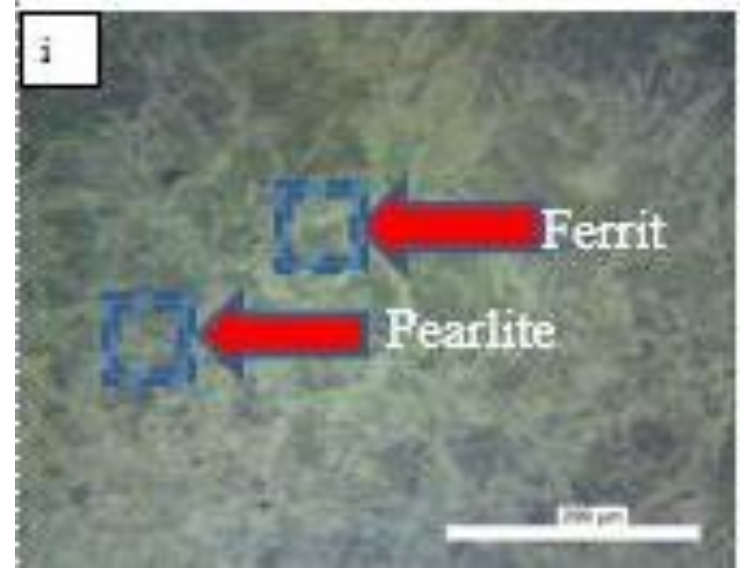

Struktur mikro yang terbentuk pada daerah weldmetal yaitu pearlite dan ferrit proses pengelasan yang dilakukan menyebabkan rata-rata fasa pearlite di daerah HAZ mengalami penurunan dibandingkan dengan daerah base metal dan meningkat di daerah weldmetal karena di pengaruhi suhu yang tinggi akibat proses pengelasan. Oleh karenanya, ada daerah weldmetal struktur mikro yang didominasi oleh fasa perlite[14].

\subsection{Pengujian Vickers Hardness (HV)}

Berdasarkan Gambar 3.12, diperlihatkan grafik nilai kekerasan pada pengelasan SMAW dengan (a)A60-V20 (b)A60-V30 (c) A60-V40 (d) A120-V20 (e) A120-V30 (f) A120V40 (g) A180-V20 (h) A180-V30 (i) A180-V40 yang menunjukkan distribusi kekerasan pada hasil pengelasan SMAW. Grafik tersebut mengindikasikan nilai kekerasan yang lebih tinggi dengan keterangan WM adalah weldmetal, BM adalah base metal dan HAZ.

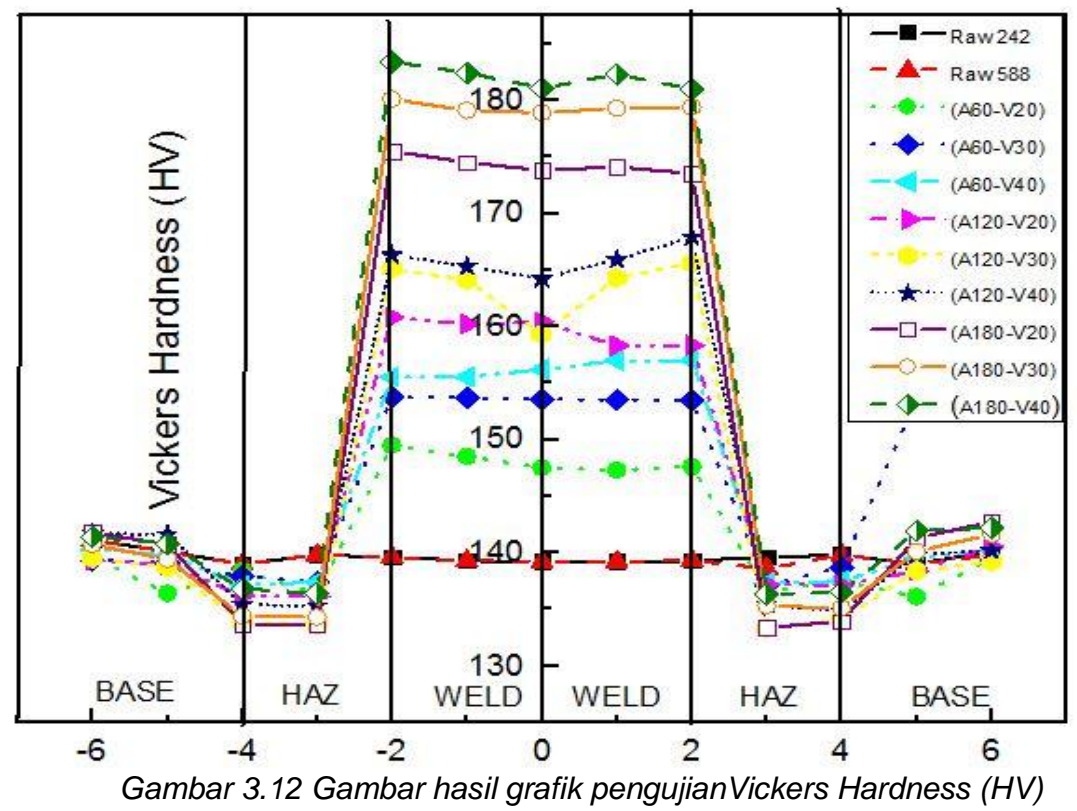




\section{KesimpULAN}

1. Pengelasan pada plat baja A242 dan A588 menghasilkan peningkatan total heat input yang dipengaruhi oleh arus dan tegangan pengelasan. Proses pengelasan juga mengakibatkan terjadinya perubahan struktur mikro dan sifat mekanik. Perubahan struktur mikro terjadi karena adanya siklus termal yaitu pemanasan yang diikuti dengan pendinginan akibat pengelasan. Struktur mikro pada daerah base metal didominasi butir-butir ferrite, sedangkan fasa pearlite lebih sedikit.

2. Penggunaan arus las yang tepat untuk pengelasan plat baja A242 dan A588 sesuai dengan heat input yang telah ditentukan adalah pada arus. Nilai tertinggi pengujian impak menggunakan arus 60A dan tegangan 20V dengan hasil 29,86 Kgf.m untuk nilai tertinggi pengujian kekerasan mikro vikers menggunakan parameter arus $180 \mathrm{~A}$ dan tegangan $40 \mathrm{~V}$ dengan hasil $182,4 \mathrm{HV}$ terjadi pada daerah weld metal, nilai tersebut meningkat $22,9 \%$ dibandingkan base metal.

\section{Daftar Pustaka}

[1] S. I. Talabi, O. B. Owolabi, J. A. Adebisi, and T. Yahaya, "Effect of welding variables on mechanical properties of low carbon steel welded joint," Adv. Prod. Eng. Manag., 2014, doi: 10.14743/apem2014.4.186.

[2] D. Pathak, R. P. Singh, S. Gaur, and V. Balu, "Experimental investigation of effects of welding current and electrode angle on tensile strength of shielded metal arc welded low carbon steel plates," 2019, doi: 10.1016/j.matpr.2020.01.146.

[3] T. Shiozaki, N. Yamaguchi, Y. Tamai, J. Hiramoto, and K. Ogawa, "Effect of weld toe geometry on fatigue life of lap fillet welded ultra-high strength steel joints," Int. J. Fatigue, 2018, doi: 10.1016/j.ijfatigue.2018.06.050.

[4] N. Yurioka, "The 70th Anniversary of Japan Welding Society-Developments in the science and Engineering of Welding and Joining toward 21th Century. Trends of Welding and Joining Engineering in Industries. Trends of welding technologies in material industries.," J. Japan Weld. Soc., 1996, doi: 10.2207/qijws1943.65.67.

[5] Y. Dong, A. P. Teixeira, and C. Guedes Soares, "Fatigue reliability analysis of butt welded joints with misalignments based on hotspot stress approach," Mar. Struct., 2019, doi: 10.1016/j.marstruc.2019.01.006.

[6] Japan Welding Engineering Society., 2006, "Advanced Welding and Joining Technologies". Tokyo: Japan Welding Society.

[7] Gea Jorge Carlos FerreiraJor,Joe ILemos Dias Mont eiroa,Antonio Joséde Ca Rvalho Gomes a,Ivanide Souza Bottb,Luís FelipeGuimarães deSouzaa, MatheusCa mpolina Mendesa, Leon ardo Sales Araújo.,2018," Influence of welding procedureand PWHT on HSLAsteel weld metals", sci://www.sciendirect./ S2238785417309249. Brazil:hal.1-11.

[8] Hsuan-Han Lai and Weite Wu., 2019, "Practical examination of the welding residual stress in view of low carbon steel ".Sci.S2214914718303453. Taiwan:hal.1-10

[9] Dony Perdana dan Ahmad Bazy Syarif., 2017, "Analisa Pengaruh Jenis Pengelasan SMAW dan FCAW Terhadap Sifat Mekanik Baja ASTM A36 pada kontruksi landside upper leg ". Indonesia:hal.1-4.

[10] Saxenna Ambuj, A.Kumarwaraswarnya, G.Madhusudhan., 2018, "Influence of welding consumable on tensile and impact properties of multipass SMAW.www.sciendirect.co.S214914717302167. India:hal.11

[11] Y.Zhao, dkk., 2019, "Effects of microstructure on crack resistance and low temperature toughness ultra-low carbon high strength steel China:hal.203-215.

[12] Leandro fr jesus dan veronica scarpini,.2018," mechanical and micro mechanical properties of SMAW welding thermally".Brazil:hal.14

[13] Cheng Chen dan Sing ping chiew,.2018," welding effect on the tensile strength of blunt joints".China:223-226.

[14] S. M. Manladan dan Zhang Z. Luo," Microstructure and mechanical properties of resistance spot welded in welding-brazing mode and resistance element welded magnesium alloy/austenitic stainless steel joints".China:124-128.

[15] Minseok Kang dan Jeongyeon Seo,.2018," Ship block assembly sequence planning considering productivity and welding deformation".korea:446. 